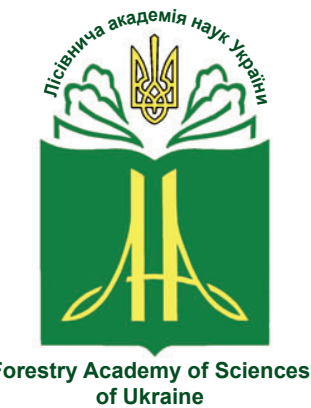

of Ukraine

Наукові праці Лісівничої академії наук України

Proceedings of the Forestry Academy of Sciences of Ukraine

http://fasu.nltu.edu.ua

https://doi.org/10.15421/412010

Article received 2020.01.10

Article accepted 2020.06.04
ISSN 1991-606X print

ISSN 2616-5015 online

(a) $\triangle$ Correspondence author

Svitlana Los

svitlana_los@ukr.net

Pushkinska str., 86, Kharkiv, 61024, Ukraine

UDC 630.165.6

\title{
Morphological variability of Quercus robur L. plus trees and clones in Podillia
}

\author{
S. Los ${ }^{1}$, L. Smashnuk ${ }^{2}$
}

The results of the study of English oak (Quercus robur L.) plus trees based on the morphological features of their leaves, acorns, and peduncles are presented. Samples were collected from both plus trees in forest stands and clones in clonal archive of English oak in Vinnytsia Region. In total, 41 trees were analyzed by 7 features of their leaves and 30 of those trees - by 9 morphological features of their acorns and peduncles. A point assessment was used for nonmetric indicators.

To compare plus trees by morphological features, the graphical method of morphotypes image representation with the usage of radar charts is suggested. Given that absolute indicators may depend on the year's weather conditions, only relative indicators assessed in points were used to plot charts.

The average indices for the trees as well as the variability level between them are determined. The most variable features were identified and offered to use for clone identification.

It has been suggested that 8 plus trees whose leaves'base is rounded are the hybrids of English and sessile oaks.

It is confirmed that all the studied plus trees of Vinnytsia origin differed in one or several morphological features of their leaves, acorns, or peduncles. However, two plus trees of Odesa origin were similar in their leaves' characteristics and two clones of Vinnytsia origin were similar in their acorns and peduncles'features.

It is noted that the use of morphological indicators of leaves and reproductive organs, taken as a whole, allows obtaining a rather complete description of a plus tree or its clone, and the usage of the graphical method allows determining the difference and similarity of individuals and their groups. Graphic images of morphotypes given as radar charts can be used to compare individuals, their groups, populations, variants in both progeny test and provenance trial, so to identify clones in clonal seed orchards.

Key words: leaf; lamina; acorn; cap; peduncle; point assessment; morphotype.

Introduction. Morphological studies have always been a basis for a systematic approach in determining plant species and cultivars. Nowadays, despite a significant role of molecular methods, morphological methods are still of great importance (Ponton et al., 2004; Pochynok, 2012). We assume they will still be important in the future as well, due to a man's visual perception of the outworld. Besides, data on plant species morphology is important enough for paleobotany (Denk, 2019). In plant breeding, clones and cultivars must be clearly different from any other cultivar by its morphological features (Lone, 2011; Singh, 2012; Chitwood et al., 2014). To simplify and unify making descriptions of cultivars, the International

Svitlana Los - Corresponding Member of the Forestry Academy of Sciences of Ukraine, PhD in Agricultural Sciences, Head of Laboratory of Forest Tree Breeding of Ukrainian Research Institute of Forestry and Forest Melioration named after G. M. Vysotsky, Pushkinska str., 86, Kharkiv, 61024, Ukraine. Tel.: 057-707-80-77,+38-097-138-97-92. E-mail: svitlana_los@ukr.net ORCID: https://orcid.org/0000-0002-63412745

2 Lyudmila Smashnyuk - researcher of Vinnitsa Forest Research Station of Ukrainian Research Institute of Forestry and Forest Melioration named after G. M. Vysotsky, Maximovicha str., 39, Vinnitsa, 21036, Ukraine. Tel.: +38-093-186-83-91. E-mail: smashnyuk.lyudmila@, yandex.ua ORCID: https://orcid.org/0000-0002-1011-5018 
Union for the Protection of New Varieties of Plants (UPOV) has developed special protocol (UPOV, 2018) and descriptors for a lot of species (Descriptor, 2008). There has not been such a descriptor for English oak (Quercus robur L.) yet. Scientists from INRA developed Assessments of oak leaf morphology (Kremer et al., 2002), but they are meant to identify interspecies differences only.

The morphological variability of English oak has been studying in Ukraine for a long time. Thus, as early as in the last century, the variability of oak morphological features was studied by P. S. Pogrebniak (1926), A.S. Machinskyi (1927), V.N. Andreyev (1927-1928), S. S. Piatnitsky (1961), A. N. Kryvosheya (1969), N. I. Davydova \& A. I. Kozhokina (1974).

Modern researchers more and more often use possibilities of computer programs for analyzing morphological features of species (Kremer et al., 2002; Viscosi et al., 2009; Bakiş \& Babaç, 2014; Fortini, Di Marzio, \& Di Pietro, 2016; Di Pietro et al., 2016; Stephana et al., 2018) or populations (Ballian et al., 2015; Batos et al., 2017), while individual variability still stays out of sight.

Meanwhile, the individual features of plus trees have a key role in both the clone identification in clonal seed orchards (CSO) and clarification of the schemes of their location.

Our previous research in Kharkiv Region identified characteristic morphological features of clones growing in CSO. We also described certain patterns of individual variability by the leaf laminas' shapes, by the form of clones' acorns (Los \& Borisova, 2002), as well as by the morphological features of the peduncles, inflorescences, and flowers (Los, 2009). Despite the notable experience in oak selection in Podillia, the morphological features of the plus trees in this region have not been thoroughly studied.

Objects and methods. The object of the research is English oak variability. The subject of the research is the English oak plus trees variability. The aim of the research was to analyze the English oak plus trees variability the Podillya by the morphological features of the vegetative and reproductive organs.

The samples of leaves, acorns, and peduncles were collected from English oak plus trees in the forest stands at Zabolotniansky and Rudnytsky forestries in SE 'Kryzhopilsky Forest Enterprise', Zhmerynsky forestry in SE 'Zhmerynsky Forest Enterprise' and from the plus trees clones in the clonal archive (CA) at Voronovystky forestry in SE 'Vinnytsia Forest Enterprise' in Vinnytsia Region (Tab. 1). We analyzed leaves of 41 plus trees, 32 of which were of Vinnytsia origin, 3 - of Ternopil origin, 2 - of Khmelnytskyi, and 4 - of Odesa origin. Peduncles and acorns were collected from 30 individuals.

The methodology of studying the variability of the oak tree included analysis of the morphological features of leaves, acorns, caps, and peduncles according to our previously suggested methods (Los \& Borisova, 2002), with some specification.

Table 1

Plus trees and sample collection location

\begin{tabular}{|c|c|c|c|c|}
\hline \multicolumn{2}{|c|}{ Plus trees location } & \multirow{2}{*}{$\begin{array}{l}\text { Plus tree index } \\
\text { by State register }\end{array}$} & \multirow{2}{*}{ Clone code } & \multirow{2}{*}{$\begin{array}{l}\text { Sample collection } \\
\text { location }\end{array}$} \\
\hline Forest Enterprise & Forestry & & & \\
\hline \multicolumn{5}{|c|}{ Vinnytsia Region } \\
\hline Vinnytsky & Prybuzke & 17 & $\mathrm{~V}-17$ & $\mathrm{CA}^{1}$ \\
\hline Vinnytsky & Yakushynetske (Yak) & $19,20,22,23,25,26$ & $\mathrm{~V}-19,20,22,23,25,26$ & $\mathrm{CA}$ \\
\hline Kryzhopilsky & Zabolotnianske (Zb) & $40,42,43$ & V- $40,42,43$ & $\mathrm{CA}$ \\
\hline Kryzhopilsky & Zabolotnianske & $\begin{array}{c}44,45,46,47,48,78,80 \\
81,84,105,108\end{array}$ & $\begin{array}{c}\mathrm{V}-44,45,46,47,48,78 \\
80,81,84,105,108\end{array}$ & $\mathrm{PT}^{2}$ \\
\hline Kryzhopilsky & Rudnytske (Rud) & $50,51,52,53,54,101$ & $\mathrm{~V}-50,51,52,53,54,101$ & $\mathrm{CA}$ \\
\hline Vinnytsky & Kalynivske (Kl) & 74 & V-74 & $\mathrm{CA}$ \\
\hline Zhmerynsky & Zhmerynske (Zhm) & $134,135,136,137$ & $\mathrm{~V}-134,135,136,137$ & PT \\
\hline \multicolumn{5}{|c|}{ Ternopil Region } \\
\hline Ternopilsky & Mykulynetske & $13,19,20$ & $\mathrm{~T}-13,19,20$ & $\mathrm{CA}$ \\
\hline \multicolumn{5}{|c|}{ Khmelnytskyi Region } \\
\hline Kamianets-Podilsky & Dunayevske & 10,60 & Kh-10, 60 & $\mathrm{CA}$ \\
\hline \multicolumn{5}{|c|}{ Odesa Region } \\
\hline Baltsky & Lisnychivske & $12,13,14,17$ & $\mathrm{O}-12,13,14,17$ & $\mathrm{CA}$ \\
\hline
\end{tabular}

${ }^{1}$ Clonal archive

${ }^{2}$ Plus tree in the forest stands 
The leaves were analyzed by 7 indicators, namely the petiole length, the leaf lamina length, the leaf lamina width, the ratio of leaf lamina width to its length, the leaf lobes depth, additional leaf lobes availability and the leaf base form. The petiole length, the length, and width of the leaf lamina were measured with a ruler.
The ratio of the leaf lamina width to its length was calculated and further assessed in points. For nonmetric indicators we applied a point assessment. Thus, the leaf lobes depth, the additional leaf lobes availability, and the leaf base were assessed in points by the scale given in Tab. 2.

Table 2

Point assessment of morphological features of English oak leaves

\begin{tabular}{|c|c|c|c|c|c|}
\hline \multirow{2}{*}{ Feature } & \multicolumn{5}{|c|}{ Points } \\
\hline & 1 & 2 & 3 & 4 & 5 \\
\hline $\begin{array}{l}\text { Width to length of } \\
\text { leaf ratio (WLLR) }\end{array}$ & $\leq 0.5$ & 0.6 & 0.7 & 0.8 & $\geq 0.9$ \\
\hline Petiole length (PtL) & $\leq 0.4 \mathrm{~cm}$ & $0.5-0.6 \mathrm{~cm}$ & $0.7-0.8 \mathrm{~cm}$ & $0.9-1.0 \mathrm{~cm}$ & $\geq 1.1 \mathrm{~cm}$ \\
\hline Leaf lobe depth (LLD) & $<1 / 3$ & appr. $1 / 3$ & appr. $1 / 2$ & appr. $2 / 3$ & $>2 / 3$ \\
\hline \multirow[t]{2}{*}{$\begin{array}{l}\text { Additional leaf } \\
\text { lobes availability } \\
\text { (ALLA) }\end{array}$} & & & & & \\
\hline & not available & $\begin{array}{l}\text { faintly marked } \\
\text { on 1-2 lobes }\end{array}$ & $\begin{array}{l}\text { faintly marked on } \\
\text { most of the lobes }\end{array}$ & $\begin{array}{l}\text { marked on } 1-2 \\
\text { lobes }\end{array}$ & $\begin{array}{l}\text { marked on most } \\
\text { of the lobes }\end{array}$ \\
\hline \multirow[t]{2}{*}{$\begin{array}{l}\text { Leaf base form } \\
\text { (LB) }\end{array}$} & & & & & \\
\hline & cuneate & acute & rounded & cordate & auriculate \\
\hline
\end{tabular}

The reproductive organs were analyzed by 9 indicators. They are the peduncle length, the peduncle straightness, the acorns number on the peduncle, the underdeveloped ovaries number on the peduncle, the cap diameter, the cap depth, the acorn diameter, the acorn length, and the acorn form. The peduncle length was measured with a ruler and further assessed in points. The sizes of the caps and acorns were defined by means of a caliper. The peduncle straightness and acorn form were assessed in points (Tab. 3).

Furthermore, we analyzed the average indices for each feature and variation coefficients. The variability level of morphological features was estimated by means of the S.O. Mamayev scale: very low $(\mathrm{CV}<7 \%)$; low $(\mathrm{CV}=8-12 \%)$; medium $(\mathrm{CV}=13$ $20 \%)$; increased $(\mathrm{CV}=21-30 \%)$; high $(\mathrm{CV}=31-40 \%)$; very high $(\mathrm{CV}>40 \%)$.

To compare plus trees by their morphological features, we suggest applying the graphical method when describing morphotypes, using at that the radar charts in MS EXCEL. Given that the metric indicators partly depend on the current year weather conditions, to make the charts we only used the relative indicators assessed in points.

Results and discussion. The plus trees had mostly medium or high variability level of their leaf size indices. The average indices of leaf length ranged from 7.5 to $12.5 \mathrm{~cm}$, and those of leaf width - from 4.2 to $10.7 \mathrm{~cm}$ (Tab. 4).

At that, the variability of the leaf lamina width of individuals within the population was higher in most cases. The ratio of lamina width to its length which accounts for the leaf lamina form ranged from 0.5 (oblong) to 0.9 (wide-elliptic). This feature variability is low and medium.

A high variability level was found in indices of the leaf lamina length, the leaf lobe depth, and additional leaf lobes availability. Certain trees' indices ranged from 0.3 (very short) to $1.2 \mathrm{~cm}$ (very long). The indices of leaf lobe depth ranged from 2 (slight depth) to 5 
(extensive depth) points. Additional lobes available to a different extent were found in 14 of the 32 trees of Vinnytsia origin. The study showed the presence of the plus trees with a rounded, cordate, and auricle leaf bases. Given that the characteristic feature of English oak leaf is a presence of auricles, it can be assumed that the 8 plus trees whose leaves have a rounded base are the hybrids of Quercus robur L. and Quercus petraea L.

Table 3

Point assessment of morphological features of the reproductive organs of English oak

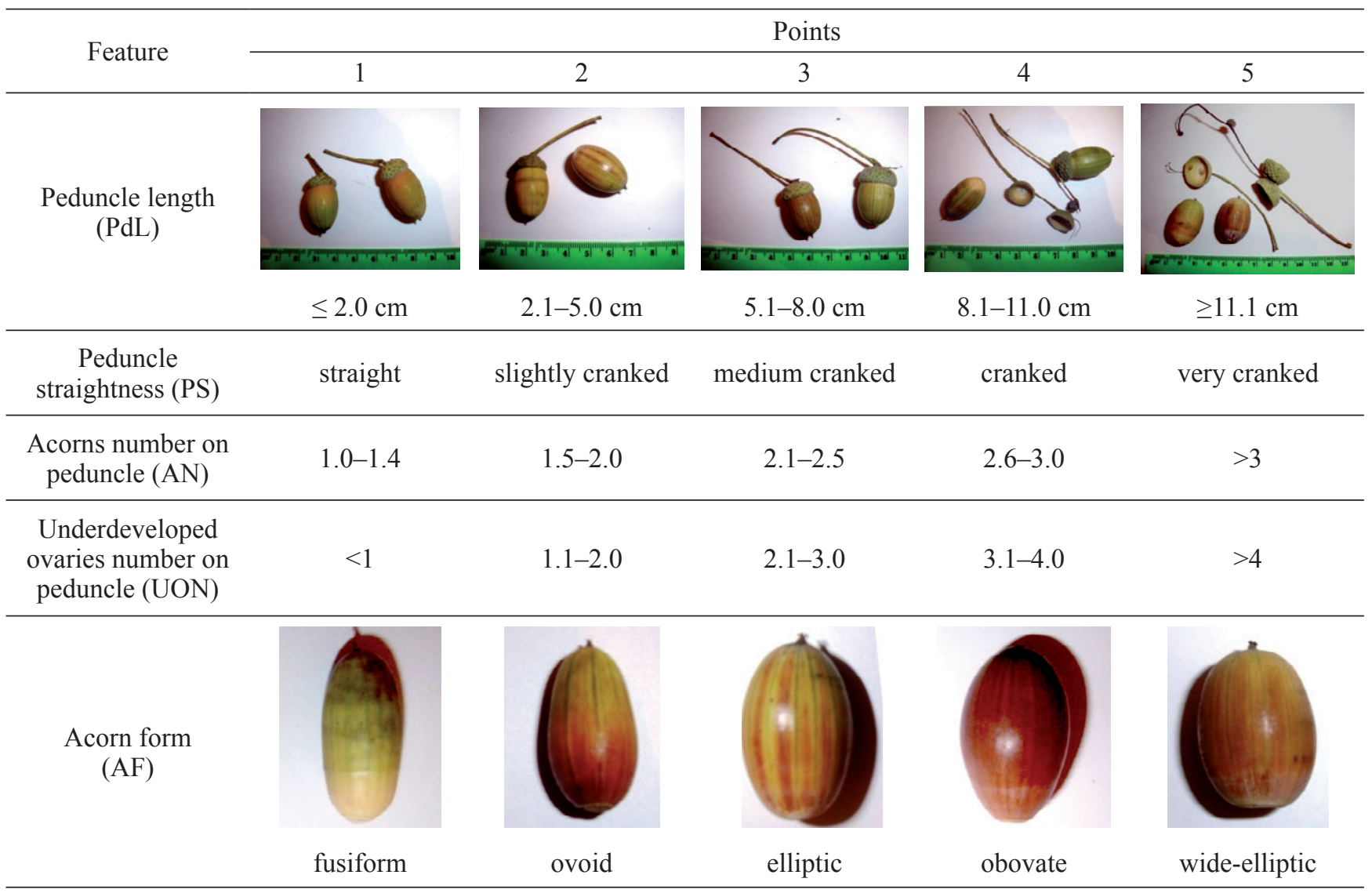

It is worth noting that the findings confirm the conclusions we had obtained before in Kharkiv Region (Los \& Borisova, 2002) which showed a very high variability level between the clones by the leaf lobe depth and additional leaf lobes availability. It also points at the fact that plus trees mostly differ by these two features and thus, the leaf lobe depth and additional leaf lobes availability should be used to identify clones. Trees with identic leaves were not found in the study.

We detected 5 of the 7 leaf morphological features which had a higher variability level. Furthermore, we assessed those 5 features in points and used the data to create graphic images of the tree leaves morphotypes by means of the radar charts. As an example, Fig. 1 contains such images for leaves of clones V-23 and $\mathrm{V}-25$, which differ in four features and are identic by one feature. The more apparent a certain feature is, the farther from the diagram center will be the angle corresponding to it (V-23). Smaller dimensions of a pentagon indicate a less marked feature (V-25). The coincidence of angles indicates the identity of the features (LS).

Morphological features of the leaves of English oak plus trees of Vinnytsia origin

\begin{tabular}{|c|c|c|c|c|c|c|c|c|c|}
\hline \multirow[b]{2}{*}{ Plus tree code } & \multicolumn{4}{|c|}{ Metric indicators } & \multicolumn{5}{|c|}{ Point } \\
\hline & $\begin{array}{l}\mathrm{LL}, \\
\mathrm{cm}\end{array}$ & $\mathrm{WL}, \mathrm{cm}$ & WLR & $\begin{array}{c}\text { PTL, } \\
\mathrm{cm}\end{array}$ & WLLR & PtL & LLD & ALLA & LB \\
\hline 1 & 2 & 3 & 4 & 5 & 6 & 7 & 8 & 9 & 10 \\
\hline V-17 & 12.5 & 8.1 & 0.6 & 0.7 & 2 & 3 & 4 & 0 & 4 \\
\hline V-19 & 10.2 & 7.3 & 0.7 & 0.7 & 3 & 3 & 2 & 2 & 3 \\
\hline $\mathrm{V}-20$ & 9.0 & 5.8 & 0.6 & 0.9 & 2 & 4 & 2 & 0 & 4 \\
\hline
\end{tabular}


Continuation of table 4

\begin{tabular}{|c|c|c|c|c|c|c|c|c|c|}
\hline 1 & 2 & 3 & 4 & 5 & 6 & 7 & 8 & 9 & 10 \\
\hline $\mathrm{V}-22$ & 8.2 & 4.2 & 0.5 & 0.5 & 1 & 2 & 2 & 1 & 3 \\
\hline $\mathrm{V}-23$ & 9.8 & 6.6 & 0.7 & 0.5 & 3 & 2 & 5 & 3 & 4 \\
\hline $\mathrm{V}-25$ & 9.4 & 5.7 & 0.6 & 0.7 & 2 & 3 & 2 & 0 & 4 \\
\hline $\mathrm{V}-26$ & 11.5 & 8.8 & 0.8 & 1.1 & 3 & 5 & 4 & 1 & 4 \\
\hline$C V, \%(Y a k)$ & 14.7 & 23.6 & 14.6 & 27.4 & 33.1 & 34.0 & 32.7 & 122.4 & 15.7 \\
\hline V-40 & 9.3 & 6.1 & 0.7 & 0.9 & 3 & 4 & 3 & 0 & 4 \\
\hline V-42 & 10.6 & 7.0 & 0.7 & 0.6 & 3 & 2 & 3 & 0 & 3 \\
\hline$V-43$ & 9.2 & 5.7 & 0.6 & 0.5 & 2 & 2 & 2 & 0 & 4 \\
\hline$V-44$ & 10.3 & 7.0 & 0.7 & 1.0 & 3 & 4 & 2 & 1 & 5 \\
\hline$V-45$ & 10.8 & 6.8 & 0.6 & 0.7 & 2 & 3 & 1 & 0 & 5 \\
\hline V-46 & 9.3 & 6.5 & 0.7 & 0.5 & 3 & 2 & 3 & 1 & 3 \\
\hline V-48 & 12.3 & 8.5 & 0.7 & 1.0 & 3 & 4 & 2 & 0 & 5 \\
\hline V-78 & 11.6 & 7.6 & 0.7 & 0.7 & 3 & 3 & 3 & 1 & 5 \\
\hline V-80 & 10.8 & 7.8 & 0.7 & 0.9 & 3 & 4 & 3 & 2 & 4 \\
\hline V-81 & 12.0 & 10.7 & 0.9 & 0.5 & 4 & 2 & 5 & 4 & 4 \\
\hline V-84 & 9.5 & 7.3 & 0.8 & 0.7 & 3 & 3 & 2 & 2 & 4 \\
\hline V-105 & 7.8 & 6.4 & 0.8 & 0.6 & 3 & 2 & 2 & 2 & 4 \\
\hline V-108 & 9.5 & 6.5 & 0.7 & 0.8 & 3 & 3 & 2 & 0 & 5 \\
\hline$C V, \%(Z b)$ & 12.7 & 17.8 & 11.2 & 24.6 & 16.9 & 29.5 & 37.3 & 119.0 & 17.7 \\
\hline V-74 & 9.0 & 5.8 & 0.6 & 0.7 & 2 & 3 & 3 & 2 & 4 \\
\hline V-50 & 11.0 & 7.7 & 0.7 & 1.1 & 3 & 5 & 3 & 0 & 4 \\
\hline V-52 & 10.6 & 7.4 & 0.7 & 1.1 & 3 & 5 & 4 & 3 & 3 \\
\hline V-53 & 9.1 & 6.5 & 0.7 & 0.9 & 3 & 4 & 4 & 0 & 3 \\
\hline V-54 & 10.6 & 6.8 & 0.6 & 1.2 & 2 & 5 & 3 & 0 & 3 \\
\hline V-101 & 10.1 & 7.0 & 0.7 & 0.7 & 3 & 3 & 2 & 0 & 4 \\
\hline$C V, \%(R d)$ & 7.1 & 6.6 & 4.4 & 22.4 & 16.0 & 20.3 & 26.3 & 205.2 & 14.9 \\
\hline V-134 & 10.2 & 6.3 & 0.6 & 0.7 & 2 & 3 & 3 & 1 & 3 \\
\hline V-135 & 11.3 & 7.5 & 0.7 & 0.3 & 3 & 1 & 4 & 0 & 5 \\
\hline V-136 & 12.3 & 8.0 & 0.6 & 1.1 & 2 & 5 & 3 & 2 & 5 \\
\hline V-137 & 12.4 & 9.0 & 0.7 & 0.9 & 3 & 4 & 1 & 0 & 5 \\
\hline$C V, \%(Z m)$ & 8.9 & 14.6 & 7.0 & 46.6 & 23.1 & 52.5 & 43.9 & 127.7 & 22.2 \\
\hline $\mathrm{CV}, \%$ (total.) & 12.3 & 17.5 & 10.9 & 29.4 & 22.7 & 34.0 & 33.8 & 120.6 & 18.7 \\
\hline $\begin{array}{c}C V, \% \text { (between } \\
\text { populations) }\end{array}$ & 6.5 & 6.2 & 4.1 & 15.9 & 11.0 & 19.3 & 11.5 & 25.6 & 11.7 \\
\hline
\end{tabular}

The comparison the individual plus trees of two micropopulations (Fig. 2A and 2B) shows the absence of identical trees by their leaf morphotypes. Trees from $\mathrm{A}$ and $\mathrm{B}$ micropopulations are similar in the width to length leaf ratio and in the petiole length. However, they differ, as micropopulations A trees have deeper leaf lobes and additional leaf lobes marked more apparently. To compare trees of different origins, the morphological features of leaves of the plus trees clones from Ternopil,
Khmelnytskyi, and Odesa Regions, which are growing in the clonal archive in Voronovytsky forestry, are given in Tab. 5. The variability of these plus trees groups is slightly lower. However, a higher variability between the clones with additional leaf lobes was observed among the plus trees clones of Kharkiv and Vinnytsia origin (Los \& Borisova, 2002). Due to a limited number of studied trees, we in no way claim to have found any geographical patterns in this research. 


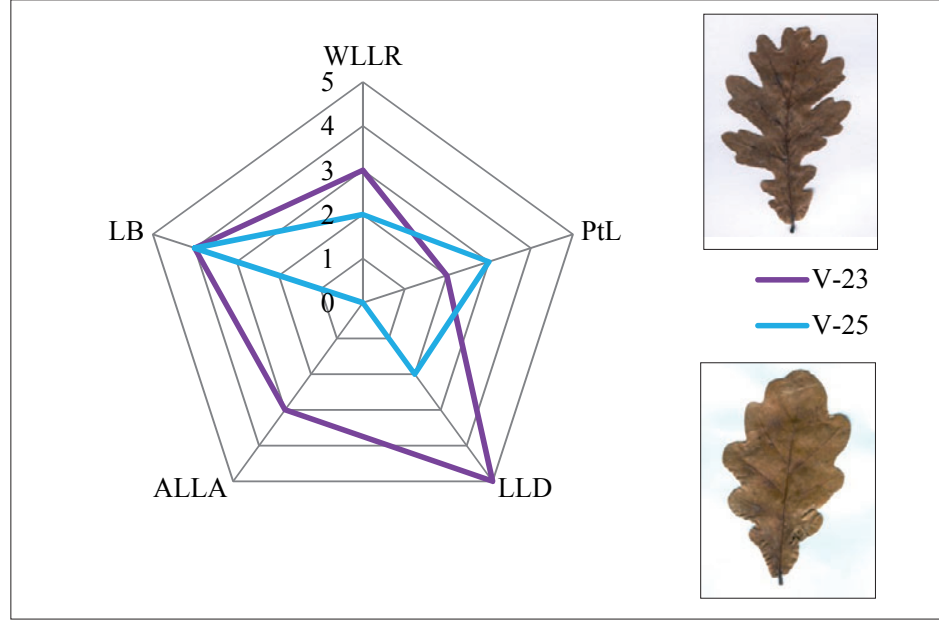

Fig. 1. The leaf morphotypes of English oak plus trees V-23 and V-25 (WLLR - width to length ratio; PtL - leaf petiole length; LLD - leaf lobes depth; ALLA - additional leaf lobes availability; LS - leaf base form)

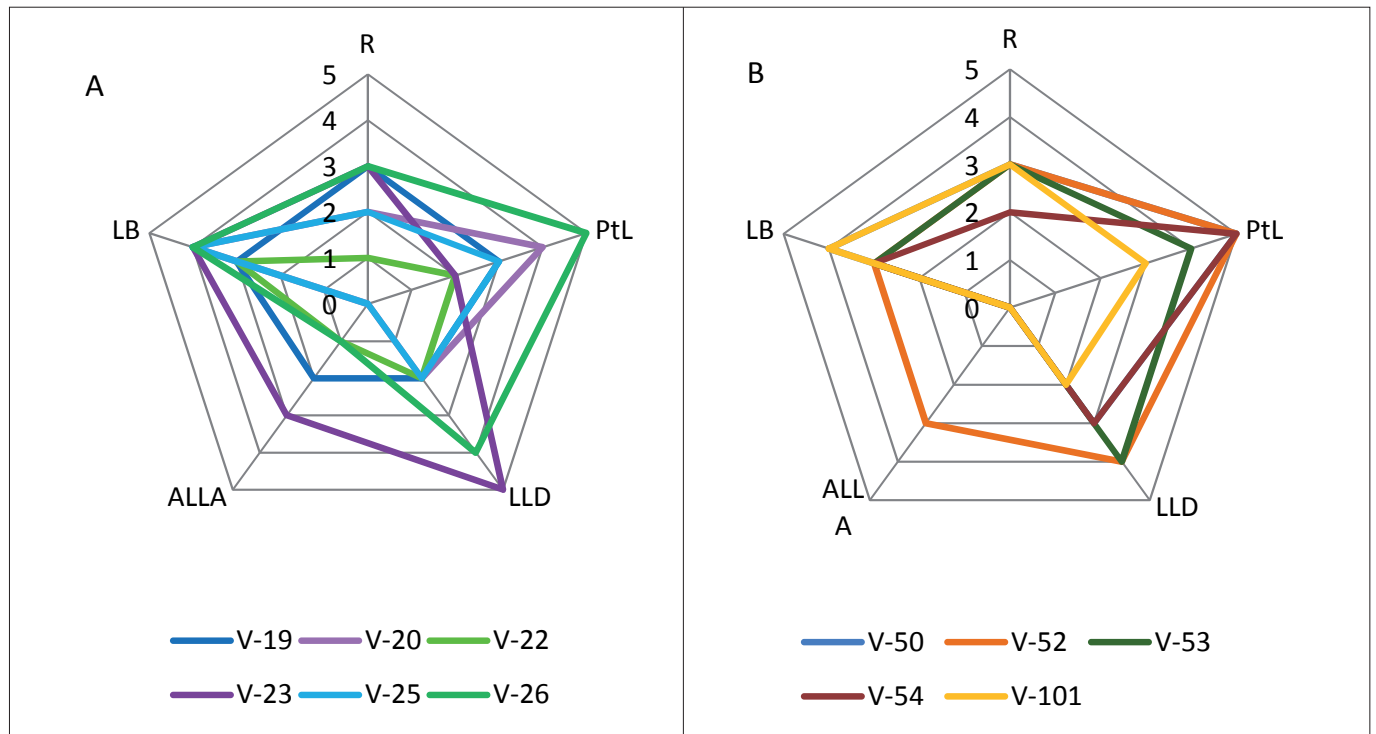

Fig. 2. The leaf morphotypes of English oak plus trees in Yakushinetsky (A) and Zhmerynsky forestries (B)

Table 5

Morphological features of the leaves of English oak plus trees of Ternopil, Khmelnytskyi and Odesa origin

\begin{tabular}{|c|c|c|c|c|c|c|c|c|c|}
\hline \multirow{2}{*}{ Plus tree code } & \multicolumn{4}{|c|}{ Metric indicators } & \multicolumn{5}{|c|}{ Points } \\
\hline & $\begin{array}{l}\mathrm{LL}, \\
\mathrm{cm}\end{array}$ & $\begin{array}{l}\mathrm{WL} \\
\mathrm{cm}\end{array}$ & WLR & $\begin{array}{c}\text { PTL, } \\
\mathrm{cm}\end{array}$ & WLLR & PtL & LLD & ALLA & LB \\
\hline 1 & 2 & 3 & 4 & 5 & 6 & 7 & 8 & 9 & 10 \\
\hline $\mathrm{T}-13$ & 11.0 & 6.9 & 0.6 & 1.0 & 2 & 4 & 4 & 1 & 3 \\
\hline $\mathrm{T}-19$ & 10.8 & 7.0 & 0.6 & 0.9 & 2 & 4 & 3 & 1 & 4 \\
\hline $\mathrm{T}-20$ & 9.9 & 5.9 & 0.6 & 0.8 & 2 & 3 & 2 & 1 & 3 \\
\hline Kh-10 & 10.0 & 6.8 & 0.7 & 1.0 & 3 & 4 & 4 & 1 & 3 \\
\hline Kh-60 & 9.5 & 7.3 & 0.8 & 0.6 & 3 & 2 & 3 & 2 & 3 \\
\hline$C V, \%(T r, K h)$ & 6.1 & 7.5 & 10.7 & 21.0 & 22.8 & 26.3 & 23.1 & 44.2 & 9.2 \\
\hline O-12 & 9.8 & 6.3 & 0.7 & 0.5 & 3 & 2 & 2 & 1 & 3 \\
\hline O-13 & 8.9 & 6.1 & 0.7 & 0.6 & 3 & 2 & 2 & 0 & 3 \\
\hline
\end{tabular}


Continuation of table 5

\begin{tabular}{cccccccccc}
\hline 1 & 2 & 3 & 4 & 5 & 6 & 7 & 8 & 9 & 10 \\
\hline $\mathrm{O}-14$ & 11.0 & 7.2 & 0.7 & 0.6 & 3 & 2 & 2 & 1 & 3 \\
$\mathrm{O}-17$ & 10.75 & 6.875 & 0.64153 & 0.85 & 2 & 4 & 2.75 & 1.5 & 3.25 \\
$\mathrm{CV}, \%(\mathrm{Od})$ & 9.6 & 7.7 & 2.8 & 24.6 & 18.2 & 40.0 & 13.9 & 71.9 & 7.8 \\
\hline
\end{tabular}

A comparison of the morphotypes of individual plus trees and their groups from these regions shows that the groups of trees are identic by the indices of the leaf petiole length only (Fig. 3). The Ternopil and Khmelnytskyi clones are also similar in the leaf lobe depth. The Khmelnytskyi clones' leaves are narrower, they have less marked additional lobes, but more apparent auricles. The Odesa clones are identical to the
Khmelnytskyi ones by 4 features, but the Odesa clones have less marked leaf lobes.

It should be noted that the leaves of clones O-12 and $\mathrm{O}-14$, although being somewhat different in size, are identical by their point assessment and, respectively, by their morphotypes (Fig. 3). Obviously, the data on morphological features of leaves only are insufficient to assess objectively a large number of trees or clones.

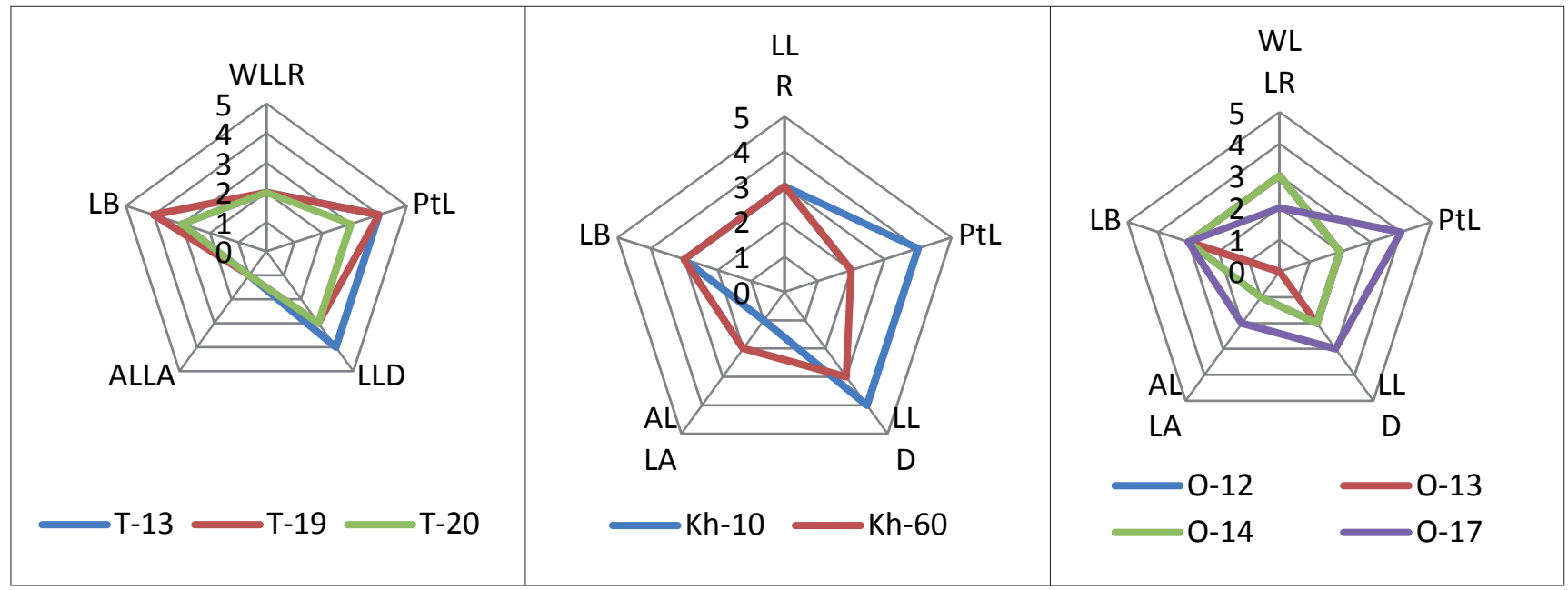

Fig. 3. The leaf morphotypes of English oak plus trees of Ternopil (A), Khmelnytskyi (B) and Odesa (C) regions

To analyze morphological features of the reproductive organs, we divided them into two groups, namely the metric indicators and point ones. Analysis of the metric indicators of the plus trees from Vinnytsia Region showed mainly medium and high variability levels. The average peduncle length ranged from 2.2 to $9.3 \mathrm{~cm}$, and the average number of acorns on the peduncle was from 1 to 2.5 pcs (Tab. 6). At that, only 6 of the 30 plus trees did not have any underdeveloped ovaries. The largest number of the latter ( 3 on average) was observed in tree V-19. The lowest variability was observed in the size of the cap and acorn. Thus, the cap diameter varied from 1.1 to $1.9 \mathrm{~cm}$, the cap's depth - from 0.5 to $1.1 \mathrm{~cm}$. The acorn diameter varied from 1.1 to $1.8 \mathrm{~cm}$ and its length from 1.0 up to $3.0 \mathrm{~cm}$.

At that, the trees were found with the caps and acorns of the same size. Therefore, these features cannot be used for identification purposes. Nevertheless, the trees differ more by the peduncle length and the number of acorns and ovaries on the peduncle. Thus, these features can be used when identifying individuals.

Table 6

Metric morphological features of acorns and peduncles of English oak plus trees of Vinnytsia origin

\begin{tabular}{cccccccc}
\hline \multirow{2}{*}{ Plus tree code } & \multicolumn{7}{c}{ Indicators } \\
\cline { 2 - 8 } & PdL, cm & AN & UON & CD, cm & CD, cm & AD, cm & AL, cm \\
\hline 1 & 2 & 3 & 4 & 5 & 6 & 7 & 8 \\
\hline V-17 & 4.5 & 1.0 & 0.5 & 1.9 & 0.9 & 1.9 & 2.8 \\
\hline V-19 & 4.5 & 1.0 & 3.0 & 1.5 & 1.0 & dna* & dna \\
V-20 & 3.4 & 1.0 & 0.7 & 1.5 & 0.8 & 1.8 & 1.8 \\
V-22 & 5.1 & 1.2 & 0.0 & 1.8 & 1.1 & 1.5 & 2.3 \\
\hline
\end{tabular}


Continuation of table 6

\begin{tabular}{|c|c|c|c|c|c|c|c|}
\hline 1 & 2 & 3 & 4 & 5 & 6 & 7 & 8 \\
\hline V-23 & 5.5 & 1.0 & 1.0 & 1.8 & 0.8 & 1.7 & 2.6 \\
\hline$C V, \%(Y a k)$ & 19.7 & 1.5 & 110.7 & 10.5 & 31.7 & 8.9 & 18.1 \\
\hline V-40 & 5.4 & 1.7 & 0.3 & 1.3 & 0.7 & 1.2 & 1.6 \\
\hline$V-43$ & 6.5 & 1.0 & 1.0 & 1.5 & 0.9 & 1.5 & 2.9 \\
\hline$V-44$ & 4.5 & 1.5 & 0.0 & 1.6 & 1.0 & 1.4 & 3.0 \\
\hline V-45 & 2.5 & 1.0 & 0.0 & 1.3 & 0.8 & 1.3 & 1.8 \\
\hline V-46 & 8.5 & 2.0 & 2.0 & 1.5 & 0.8 & 1.3 & 1.8 \\
\hline V-48 & 5.0 & 1.0 & 1.0 & 1.3 & 1.0 & 1.3 & 2.8 \\
\hline V-78 & 6.3 & 1.5 & 2.0 & 1.1 & 0.5 & 1.2 & 3.0 \\
\hline V-80 & 6.2 & 1.7 & 1.3 & 1.3 & 0.8 & dna & dna \\
\hline V-81 & 2.7 & 1.3 & 1.0 & 1.3 & 0.7 & 1.2 & 2.0 \\
\hline V-84 & 2.2 & 1.3 & 0.0 & 1.5 & 0.7 & 1.6 & 2.0 \\
\hline V-108 & 5.5 & 2.0 & 0.0 & 1.5 & 0.7 & 1.3 & 3.5 \\
\hline$C V, \%(Z b)$ & 38.8 & 25.3 & 9.7 & 10.9 & 21.5 & 10.1 & 27.7 \\
\hline $\mathrm{V}-50$ & 4.5 & 1.3 & 0.2 & 1.7 & 0.7 & 1.8 & 2.6 \\
\hline V-52 & 5.3 & 1.0 & 0.3 & 1.6 & 0.6 & 1.6 & 2.3 \\
\hline V-53 & 5.3 & 1.0 & 0.7 & 1.3 & 0.9 & 1.4 & 1.8 \\
\hline V-54 & 7.5 & 1.0 & 1.0 & 1.5 & 0.7 & 1.8 & 2.7 \\
\hline$C V, \%(R d)$ & 23.1 & 15.4 & 68.1 & 13.0 & 15.1 & 11.4 & 16.9 \\
\hline V-134 & 5.0 & 1.0 & 1.0 & 1.4 & 0.6 & 1.4 & 2.5 \\
\hline V-135 & 9.3 & 1.5 & 2.0 & dna & dna & dna & dna \\
\hline V-136 & 5.5 & 2.3 & 0.3 & 1.9 & 0.9 & 1.4 & 1.9 \\
\hline V-137 & 3.8 & 2.5 & 0.0 & 1.1 & 0.5 & 1.3 & 2.0 \\
\hline$C V, \%(\mathrm{Zm})$ & 40.8 & 38.0 & 110.6 & 24.8 & 25.3 & 5.0 & 15.1 \\
\hline$C V, \%$ (total) & 40.6 & 32.8 & 100.3 & 15.1 & 27.2 & 14.9 & 22.3 \\
\hline $\begin{array}{c}C V, \% \text { (between } \\
\text { populations) }\end{array}$ & 9.5 & 26.4 & 31.0 & 7.9 & 21.3 & 11.2 & 5.7 \\
\hline
\end{tabular}

*dna - data not available

The plus trees clones from other regions have mainly shorter peduncles and generally lower variability levels as compared to those of Vinnytsia origin (Tab. 7).
To make the morphotypes diagrams, we used the morphological features of the plus trees' reproductive organs assessed in points (Tab. 8).

Table 7

\section{Metric morphological features of acorns and peduncles of English oak plus trees of Ternopil, Khmelnytskyi, and Odesa origin}

\begin{tabular}{|c|c|c|c|c|c|c|c|}
\hline \multirow{2}{*}{ Plus tree code } & \multicolumn{7}{|c|}{ Indicators } \\
\hline & $\mathrm{PdL}, \mathrm{cm}$ & AN & UON & $\mathrm{CD}, \mathrm{cm}$ & $\mathrm{CD}, \mathrm{cm}$ & $\mathrm{AD}, \mathrm{cm}$ & $\mathrm{AL}, \mathrm{cm}$ \\
\hline $\mathrm{T}-19$ & 3.7 & 1 & 0.3 & 1.6 & 0.8 & 1.7 & 2.9 \\
\hline $\mathrm{T}-20$ & 7 & 2 & 0 & 1.5 & 0.7 & 1.7 & 2.7 \\
\hline Kh-10 & 2.8 & 1 & 0.5 & 1.6 & 0.6 & 2.5 & 1.7 \\
\hline $\mathrm{O}-12$ & 2.3 & 1.25 & 0.3 & 1.4 & 1.0 & & \\
\hline O-13 & 4 & 1.25 & 0.25 & 1.5 & 0.7 & 1.5 & 2.1 \\
\hline $\mathrm{O}-17$ & 5.5 & 1.5 & 0.5 & 1.5 & 0.6 & 1.5 & 2.0 \\
\hline$C V, \%($ total $)$ & 42.0 & 28.2 & 61.4 & 4.7 & 18.2 & 23.3 & 22.3 \\
\hline
\end{tabular}


Fig. 4 shows an example of a graphical comparison of the morphotypes of plus trees' reproductive organs (V-43, V-46, and Kh-1).

The more apparent the feature is, the farther from the diagram center will be the angle corresponding to it, e. g. the acorn form of tree Kh-10. Smaller sizes of a pentagon point at the fact that the features are less apparent (V-43), the same angles indicate the identity of the features, e. g. the number of acorns and ovaries in trees V-43 and V-46.

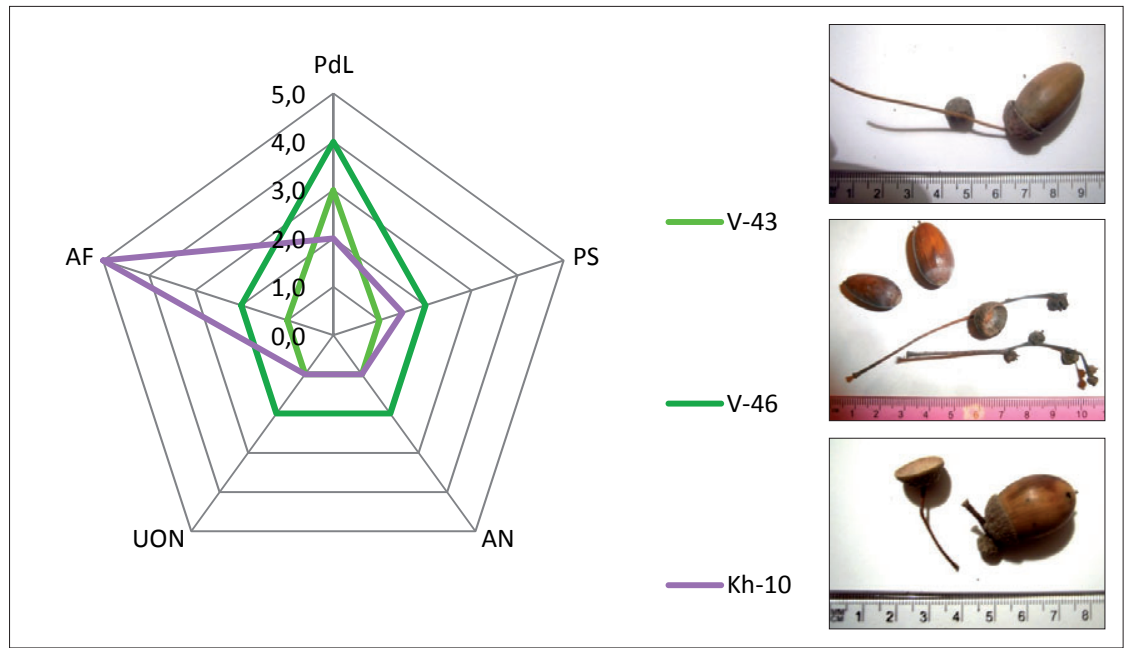

Fig. 4. The reproductive organs morphotypes of English oak plus trees V-43, V-46, and Kh-10

( $\mathrm{PdL}$ - peduncle length; PS - peduncle straightness; AN - acorns number on peduncle; UON - underdeveloped ovaries number on peduncle; $\mathrm{AF}$ - acorn form)

Table 8

Metric morphological features of acorns and peduncles of English oak plus trees of Vinnitsya, Ternopil, Khmelnytskyi and Odesa origin (points)

\begin{tabular}{cccccc}
\hline \multirow{2}{*}{ Plus tree code } & \multicolumn{5}{c}{ Indicators } \\
\cline { 2 - 6 } & PdL & PS & AN & UON & AF \\
\hline V-17 & 2 & 3 & 4 & 1.0 & 6 \\
\hline V-19 & 2.0 & 1.0 & 1.0 & 3.0 & 5.0 \\
V-20 & 2.0 & 2.0 & 1.0 & 1.0 & 3.0 \\
V-22 & 2.0 & 1.3 & 1.0 & 1.0 & 5.0 \\
V-23 & 3.0 & 1.7 & 1.0 & 1.0 & 4.0 \\
\hline V-40 & 3.0 & 1.0 & 2.0 & 1.0 & 4.0 \\
V-43 & 3.0 & 2.4 & 1.0 & 1.0 & 1.0 \\
V-44 & 3.0 & 1.0 & 2.0 & 1.0 & 4.0 \\
V-45 & 2.0 & 1.0 & 1.0 & 1.0 & 5.0 \\
V-46 & 2.0 & 1.0 & 2.0 & 2.0 & 2.0 \\
V-48 & 4.0 & 2.0 & 1.0 & 1.0 & 3.0 \\
V-78 & 3.0 & 1.0 & 2.0 & 2.0 & 3.0 \\
V-80 & 3.0 & 1.0 & 2.0 & 2.0 & dna \\
V-81 & 3.0 & 1.0 & 1.0 & 1.0 & 2.0 \\
V-84 & 2.0 & 1.0 & 1.0 & 1.0 & 5.0 \\
V-108 & 2.0 & 1.0 & 2.0 & 1.0 & 3.0 \\
\hline V-50 & 3.0 & 2.0 & 1.0 & 1.0 & 5.0 \\
V-52 & 2.0 & 1.0 & 1.0 & 1.0 & 3.0 \\
V-53 & 2.0 & 3.0 & 1.0 & 1.0 & 2.0 \\
V-54 & 2.0 & 2.8 & 1.0 & 1.0 & 2.0 \\
\hline V-134 & 3.0 & 2.0 & 1.0 & 1.0 & 3,0 \\
\hline & 3.0 & 4.0 & & & \\
\hline
\end{tabular}




\begin{tabular}{|c|c|c|c|c|c|}
\hline 1 & 2 & 3 & 4 & 5 & 6 \\
\hline V-135 & 4.0 & 5.0 & 2.0 & 2.0 & dna \\
\hline V-136 & 2.0 & 1.0 & 3.0 & 1.0 & 3.0 \\
\hline V-137 & 2.0 & 1.0 & 3.0 & 1.0 & 3.0 \\
\hline T-19 & 2.0 & 2.0 & 1.0 & 1.0 & 2.0 \\
\hline $\mathrm{T}-20$ & 3.0 & 1.0 & 2.0 & 1.0 & 2.0 \\
\hline Kh-10 & 2.0 & 1.5 & 1.0 & 1.0 & 5 \\
\hline O-12 & 2.0 & 1.0 & 1.0 & 1.0 & dna \\
\hline O-13 & 2.0 & 2.0 & 1.0 & 1.0 & 2.0 \\
\hline O-17 & 3.0 & 1.0 & 2.0 & 1.0 & 5.0 \\
\hline
\end{tabular}

Comparison of the plus trees morphotypes of two micropopulations (forest stands of Rudnytsky and Zhmerynsky forestries in Vinnytsia Region) is given in Fig. 5.

The trees from forest stands of two forestries are similar in the acorn form and differ in the rest of the features. On the whole, the group of trees from Rudnytsky forestry has more apparent features (a longer peduncle, more acorns, and ovaries on a peduncle). In contrast, the group of trees from Zhmerynsky forestry has more cranked peduncles. As we can see, most of the plus trees differ in at least one feature, but trees V-45 and V-84 are similar in all reproductive organs features (Fig. 5, 6 A). At that, on comparing these trees by the leaf morphotypes, we found that they differ in four of five features (Fig. 6 B).

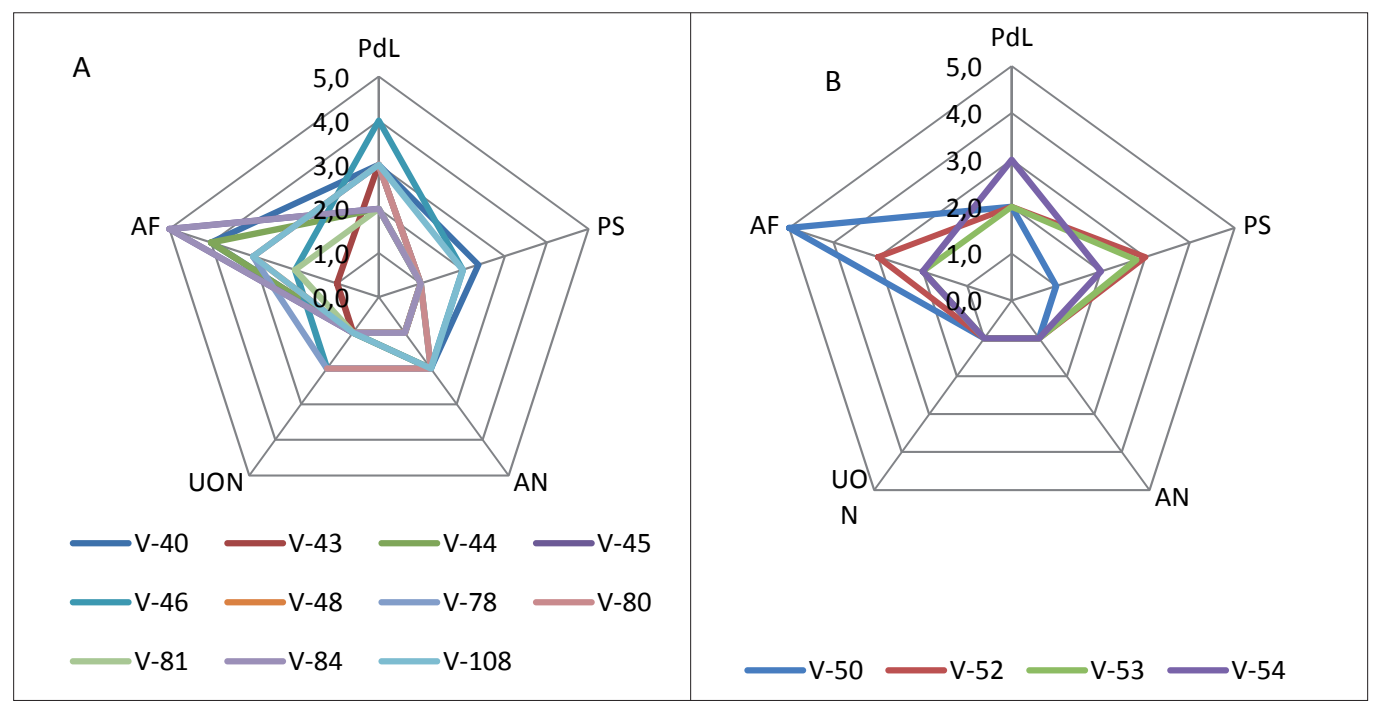

Fig. 5. The reproductive organs morphotypes of English oak plus trees of Rudnytsky (A) and Zhmerynsky forestries (B)

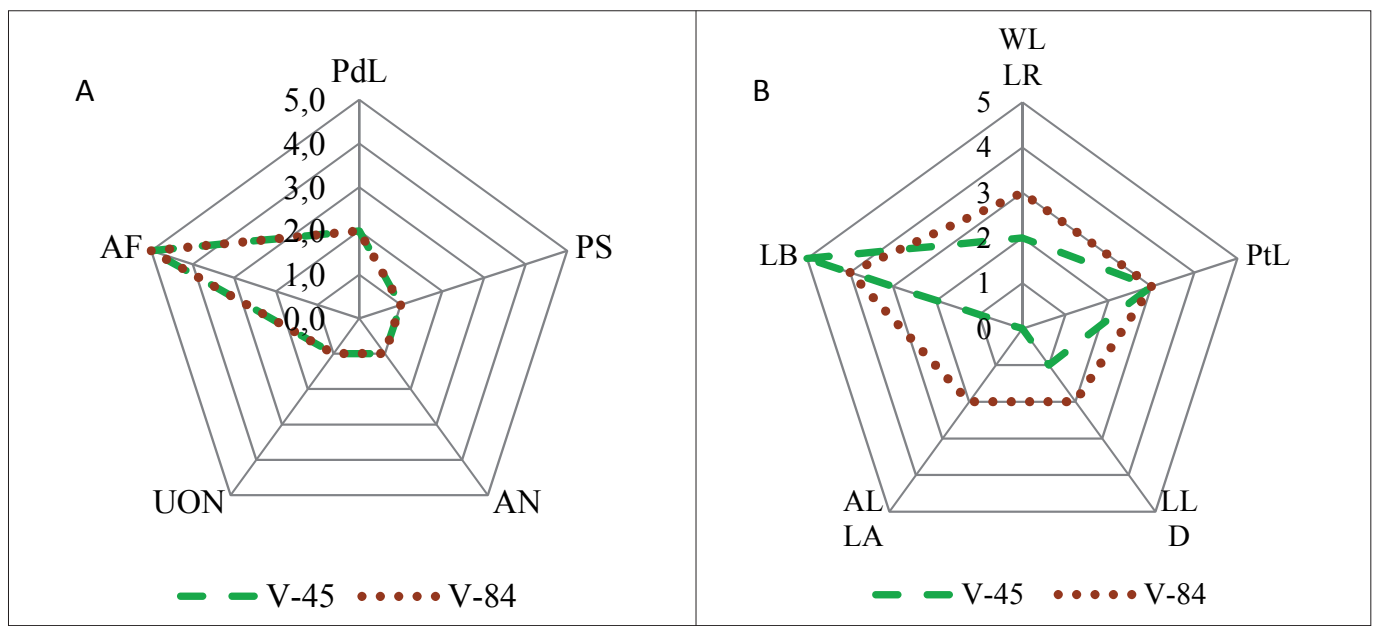

Fig. 6. Comparison of plus trees V-45 and V-84: morphotypes of reproductive organs (A) and leaves (B) 
Usage of morphological features of leaves and reproductive organs, taken as a whole, allows obtaining a rather complete description necessary to identify a plus tree or a clone. Furthermore, the graphical method helps to determine the difference and similarity of individuals and their groups.

Conclusions. Analysis of the leaves morphological features of the plus trees of Vinnytsia origin revealed such variability levels: low and medium - for indicators of the leaf base and the width to length leaf ratio; medium and increased - for the indicators of the leaf lamina size; high - for the lamina length, the leaf lobes depth and additional leaf lobes availability.

Among 7 morphological features of leaves, the most informative for clone identification are the leaf base, the width to length ratio, the leaf lamina length, the leaf lobes depth, and additional leaf lobes availability.

It has been suggested that 8 of the 32 plus trees whose leaves have a rounded base are the introgressive hybrids of Quercus robur L. and Quercus petraea L.

All studied plus trees of Vinnytsia origin differed in one or more leaves morphological features. At that, two of the four clones of Odesa origin, namely O-12 and O-14, had similar leaves.

The variability levels of metric indicators for the reproductive organs of the plus trees were mostly medium and increased. The sizes of the cap and acorn had the lowest variability level. At that, the variability levels of both the peduncle length and the number of acorns and ovaries on it were higher. The latter features can be used to plus trees clone identification.

Most of the studied plus trees differ in one or several morphological features of their reproductive organs. However, trees V-45 and V-84 are similar in all the features.

Usage of leaves and reproductive organs morphological features, taken as a whole, allows obtaining a rather complete description of a plus tree or its clone. Graphic images of morphotypes given as radar charts can be used to compare certain individuals, their groups and populations, variants in progeny test, and provenance trial to identify clones on CSO.

Acknowledgements. The authors are grateful to colleagues from Vinnitsa Forest Research Station and Ukrainian Research Institute of Forestry and Forest Melioration for assistance during part of the fieldwork.

\section{References}

Andreev, V.N. (1927-1928). Homological ranks of some oaks. Work on applied botany, genetics and selection. XVIII (2), 371- 454 (in Russian).

Ballian, D., Hodžić, M. M., Bogunić, F., \& Parpan T. V. (2015). Morphological variability of differentiated by altitude above sea level population of pedunculate oak (Quercus robur L.) in Bosnia and Herzegovina. Biol. Stud, 9 (3-4), 155-168. https://doi.org/10.30970/ sbi.0903.436
Bakiş, Y, \& Babaç, M.T. (2014). Morphological variability of acorns and its taxonomic significance in Quercus L. from Turkey. Bangladesh Journal of Botany, · 43 (3), 293-299. https://doi.org/10.3329/bjb. v43i3.21601

Batos, B., Miljković, D., Perović, M., \& Orlović, S. (2017). Morphological variability of Quercus robur L. leaf in Serbia. Genetika. 1, 529-541. https://doi. org/10.2298/GENSR1702529B

Chitwood, D.H. Ranjan, A., Martinez, C.C., Headland, L.R., Thiem, T., Kumar, R., ... Sinha N.R. (2014) A Modern Ampelography: A Genetic Basis for Leaf Shape and Venation Patterning in Grape1. Plant Physiology, 164, 259-272. https://doi.org/10.1104/ pp.113.229708

Davydova, N. I., \& Kozhokina,A. I. (1974). Endogenous and population variability of English oak. Forestry and Forest Melioration, 38, 79-85.

Denk, T., Tuncay H.G., Bouchal, J.M., \& Kallanxhic, M.-E. (2019). The Pleistocene flora of Bezhan, southeast Albania: early appearance of extant tree species. Historical Biology, 1-23 Published Online: 20 May 2019. https://doi.org/10.1 080/08912963.2019.1615061

Descriptors for hazelnut (Corylus avellana L.). (2008). Bioversity, FAO and CIHEAM. Bioversity International, Rome, Italy; Food and Agriculture Organization of the United Nations, Rome, Italy; International Centre for Advanced Mediterranean Agronomic Studies, Zaragoza, Spain, 64. Retrieved from: https://www.bioversityinternational.org/fileadmin/_migrated/uploads/tx news/Hazelnut 1285 01.pdf

Di Pietro, R., Di Marzio, P., Medagli, P., Misano, G., Silletti, G.N., Wagensommer, R.P., \& Fortini, P. (2016). Evidence from multivariate morphometric study of the Quercus pubescens complex in southeast Italy. Botanica Serbica, 40 (1), 83-100. https://doi. org/10.5281/zenodo.48865

Fortini, P., Di Marzio, P., \& Di Pietro R. (2015). Differentiation and hybridization of Quercus frainetto, Q. petraea, and Q. pubescens (Fagaceae): insights from macro-morphological leaf traits and molecular data. Plant Syst Evol., 301, 375-385. https://doi.org/10.1007/s00606-014-1080-2

Kremer, A, Dupoueyb, J. L., Deansc, J. D., Cottrelld, J., Csaikle, U., Finkeldeyf, R.,... Badeaub, V. (2002). Leaf morphological differentiation between Quercus robur and Quercus petraea is stable across western European mixed oak stands. Annals of Forest Science, 59, 777-787. https://doi.org/10.1051/forest:2002065

Krivosheya, A.N. (1969). Phenological forms and variability of morphological features of common oak. Works of Kharkov agricultural institute named after V.V. Dokuchaev, 86 (123), 111-117 (in Russian).

Lone A.A., Bashir, A., Tewari S.K., \& Majeed, M. (2011) Characterization and identification of leaf morphology of Populus deltoides Bartr. Clones. Forestry Studies in China, 13 (4), 270-273. https:// doi.org/10.1007/s11632-013-0404-6 
Los, S.A., \& Borysova, V.V. (2002). Methodological approaches to study variability of Quercus robur L. morphological traits. Bulletin KhNAU, 2, 74-79 (in Ukrainian).

Los, S. (2009). Methodic approach to investigation of English oak (Quercus robur L.) individual variability by morphology of female reproductive structures. Forestry and Forest Melioration, 115, 20-27. Retrieved from: http://dspace.nbuv.gov.ua/ handle/123456789/16411. (in Ukrainian with English summary).

Machinsky, A. S. (1927). About the races of oak. Forest science and forestry, 4, 34-66 (in Russian).

Pyatnitsky, S. S. (1961). Textbook on forest breeding: for forestry universities of the USSR. Moscow: Agricultural Publishing House (in Russian).

Pochynok, T. (2012). Is there a place for plant morphology in the contemporary research? Modern Phytomorphology, 2, 13-16. Retrieved from: https:// www.phytomorphology.com/archive/mp-volume-2year-2012.html

Pogrebnyak, P.S. (1926). The experience of study of the racial composition of Quercus robur L. (English oak) in the Trostyanets forestry in Ukraine. Forest science and forestry, 3, 40-45 (in Russian).

Ponton, S., Dupouey, J.-L., \& Dreyer, E. (2004). Leaf morphology as species indicator in seedlings of Quercus robur L. and Q. petraea (Matt.) Liebl. modulation by irradiance. Annals of Forest Science, 61, 73-80. https://doi.org/10.1051/forest:2003086

Singh M.K. (2012). Morphlogical markers for identification of populous deltoides clones in nursery. HortFlora Research Spectrum, 1 (4), 383-384. Retrieved from:https:file://D:/PERSON/ S VETA/S TAT TI/ $2020 /$ Ліс і в н $\% 20$ ака \% 20 морф\%20він/20.4_Morphological_markers_for poplar cl.pdf

Stephana, J.M., Teenya, P.W., Vessellab, F., \& Schironeb, B. (2018). Oak morphological traits: Between taxa and environmental variability. Flora, 243, 32-44. https://doi.org/10.1016/j. flora.2018.04.001

Viscosi, V., Lepais, O., Gerber, S., \& Fortini, P. (2009). Leaf morphological analyses in four European oak species (Quercus) and their hybrids: A comparison of traditional and geometric morphometric methods. Plant Biosystems, 10, 1-11. https://doi. org/10.1080/11263500902723129

UPOV (2018). Protocol for tests on distinctness, uniformity and stability Populus L. 16 Retrieved from: https:/cpvo.europa.eu/sites/ default/files/ documents/populus.pdf

\section{Морфологічна мінливість плюсових дерев і клонів Quercus robur L. на Поділлі}

\author{
С. А. Лось ${ }^{1}$, Л.В. Смашнюк ${ }^{2}$
}

Представлені результати вивчення плюсових дерев Quercus robur L. за морфологічними показниками листків, жолудів та плодоносів. Зразки заготовлені $з$ плюсових дерев у насадженнях та 3 клонів на архівно-маточній плантації дуба звичайного у Вінницькій області. Проаналізовані 41 дерево за сімома показниками листків і 30 з них - за дев'ятьма морфологічними показниками жолудів і плодоносів. Неметричні показники оцінювали балами.

Запропоновано графічний метод зображення морфотипів із використанням кругових пелюсткових діаграм для порівняння плюсових дерев за морфологічними ознаками. Враховуючи те, що абсолютні показники можуть залежати від погодних умов року, для побудови діаграм використано лише відносні показники, виражені у балах.

Визначено середні показники дерев та рівень їхньої мінливості. Так, мінливість розмірів листків $\epsilon$ переважно середньою та підвищеною, а форми листка - низькою та середньою. Рівень мінливості за шириною листка у переважній більшості випадків був вищим. За показниками довжини черешка листка та наявності додаткових лопатей відмічено високий рівень мінливості. Різну кількість додаткових лопатей нараховано у 14 клонів із 32. Виявлені плюсові дерева із заокругленою, серцеподібною та вушкоподібною основою листків. Визначено найбільш мінливі ознаки, які запропоновано використовувати для ідентифікації клонів.

Висловлено припущення, що вісім плюсових дерев, листки яких мають заокруглену основу, є гібридами між дубами звичайним та скельним.

Серед репродуктивних ознак найменшою мінливістю вирізнявся показник розмірів плиски та жолудя. Найбільшу мінливість мали довжина плодоноса та кількість зав'язей і жолудів на ньому, i саме ці ознаки запропоновано використовувати для ідентифікації клонів. Середня кількість жолудів на плодоносі становила від 1 до 2,5 шт., причому лише у шести плюсових дерев на плодоносах не відмічено недорозвинених зав' язей.

Лось Світлана Анатолївна - член-кореспондент Лісівничої академії наук України, кандидат сільськогосподарських наук, завідувач лабораторії селекції. Український науково-дослідний інститут лісового господарства та агролісомеліорації ім. Г. М. Висоцького, вул. Пушкінська, 86, м. Харків, 61024, Україна. Тел.: 057-707-80-77, +38-097-138-97-92. E-mail: svitlana_los@ukr.net ORCID: https://orcid.org/0000-0002-6341-2745

Смашнюк Людмила Володимирівна - науковий співробітник ДП «Вінницька лісова науково-дослідна станція» Українського науково-дослідного інституту лісівництва та агролісомеліорації ім. Г.М. Висоцького, вул. Максимовича, 39, м. Вінниця, 21036, Україна. Tel.: +38-093-186-83-91. E-mail: smashnyuk. lyudmila@yandex.ua ORCID: https://orcid.org/0000-0002-10115018 
Обстежені плюсові дерева вінницького походження відрізнялися за однією або декількома морфологічними ознаками листків, жолудів або плодоносів. Водночас виявлено два плюсових дерева одеського походження, подібних за формою листків, і два клони вінницького походження, подібних за ознаками жолудів та плодоносів.

Використання морфологічних показників листків і репродуктивних органів у комплексі дає змогу скласти доволі повну характеристику плюсового дерева або його клону, а застосування графічного методу - оцінити відмінності й подібності індивідів та їхніх груп. Графічні зображення морфотипів у вигляді пелюсткових діаграм можуть бути використані як для порівняння індивідів, їхніх груп, популяцій, варіантів у випробних і географічних культурах, так і для ідентифікації клонів на клонових насінних плантаціях.

Ключові слова: листок; пластинка; жолудь; плиска; плодоніжка; балове оцінювання; морфотип.

\section{Морфологическая \\ изменчивость плюсовых деревьев и клонов Quercus robur L. на Подолье}

\author{
С. А. Лось ${ }^{1}$, Л.В. Смашнюк ${ }^{2}$
}

Представлены результаты изучения плюсовых деревьев Quercus robur L. по морфологическим показателям листьев, желудей и плодоносов. Образцы заготовлены с плюсовых деревьев в насаждениях и с клонов на архивно-маточной плантации дуба обыкновенного в Винницкой области. Проанализировано 41 дерево по семи показателям листьев и 30 из них - по девяти морфологическим показателям желудей и плодоносов. Для неметрических показателей использовали бальную оценку.

Предложен графический метод изображения морфотипов с использованием круговых

Лось Светлана Анатольевна - член-корреспондент Лесной академии наук Украины, кандидат сельскохозяйственных наук, заведующий лабораторией селекции. Украинский научно-исследовательский институт лесного хозяйства и агролесомелиорации им. Г.Н. Высоцкого, ул. Пушкинская, 86, г. Харьков, 61024, Украина. Тел.: 057-707-80-77, +38-097138-97-92. E-mail: svitlana_los@ukr.net ORCID: https://orcid. org/0000-0002-6341-2745

2 Смашнюк Людмила Владимировна - научный сотрудник ГП «Винницкая лесная научно-исследовательская станция» Украинского научно-исследовательского института лесного хозяйства и агролесомелиорации им. Г.Н. Высоцкого, ул. Максимовича, 39, г. Винница, 21036, Украина. Тел.: +38-093-186-83-91. E-mail: smashnyuk.lyudmila@yandex.ua ORCID: https://orcid. org/0000-0002-1011-5018 лепестковых диаграмм для сравнения плюсовых деревьев по морфологическим признакам. Учитывая то, что абсолютные показатели могут зависеть от погодных условий года, для построения диаграмм использованы только относительные показатели, выраженные в баллах.

Определены средние показатели деревьев и уровень их изменчивости. Уровень изменчивости размеров листьев был преимущественно средним и повышенным, а формы листка - низким и средним. Уровень изменчивости ширины листка в подавляющем большинстве случаев был более высоким. По показателям длины черешка листка и наличия дополнительных лопастей отмечен высокий уровень изменчивости. Дополнительные лопасти, выраженные в разной степени, выявлены в листьях 14 клонов из 32. Отмечено наличие плюсовых деревьев с округлой, сердцевидной и ушкообразной основой листка. Выявлены наиболее изменчивые признаки, и предложено их использование для идентификации клонов.

Высказано предположение, что восемь плюсовых деревьев, листья которых имеют округлую форму основы, являются гибридами между дубами обыкновенным и скальным.

Среди репродуктивных признаков наименьшей изменчивостью отличался показатель размеров плюски и желудя. Наибольший уровень изменчивости отмечен у таких показателей, как длина плодоноса, количество желудей и завязей на нем, и именно эти признаки предложено использовать для идентификации. Среднее количество желудей на плодоносе составляло от 1 до 2,5 шт., при этом только у шести плюсовых деревьев на плодоносах не отмечено недоразвитых завязей.

Показано, что все обследованные плюсовые деревья винницкого происхождения отличались по одному или нескольким морфологическим признакам листьев, желудей или плодоносов. В то же время выявлено два плюсовые деревья одесского происхождения, подобных по форме листьев, и два клона винницкого происхождения, подобных по признакам желудей и плодоносов.

Отмечено, что использование морфологических показателей листьев и репродуктивных органов в комплексе позволяет составить достаточно полную характеристику плюсового дерева или его клона, а применение графического метода - определить различие и сходство индивидов и их групп. Графические изображения морфотипов в виде лепестковых диаграмм могут быть использованы как для сравнения индивидуумов, их групп, популяций, вариантов в испытательных и географических культуpax, так и для идентификации клонов на клоновых семенных плантациях.

Ключевые слова: листок; пластинка; желудь; плюска; плодоножка; бальная оценка; морфотип. 